medRxiv preprint doi: https://doi.org/10.1101/2020.11.02.20221481; this version posted November 4, 2020. The copyright holder for this preprint (which was not certified by peer review) is the author/funder, who has granted medRxiv a license to display the preprint in

It is made available under a CC-BY-NC-ND 4.0 International license .

\title{
Size matters: large copy number losses reveal novel Hirschsprung disease genes
}

Laura Kuil ${ }^{1}$, Katherine C. MacKenzie ${ }^{1}$, Clara S Tang ${ }^{3,4}$, Jonathan D. Windster ${ }^{1,2}$, Thuy Linh Le ${ }^{5}$, Anwarul Karim ${ }^{3}$, Bianca M. de Graaf ${ }^{1}$, Robert van der Helm ${ }^{1}$, Yolande van Bever ${ }^{1}$, Cornelius E.J. Sloots ${ }^{2}$, Conny Meeussen ${ }^{2}$, Dick Tibboel ${ }^{2}$, Annelies de Klein ${ }^{1}$, René M. H. Wijnen², Jeanne Amiel ${ }^{5}$, Stanislas Lyonnet ${ }^{5}$, ${ }^{7}$, Maria-Mercè Garcia-Barcelo ${ }^{3}$, Paul K.H. Tam ${ }^{3,4}$, Maria M. Alves ${ }^{1}$, Alice Brooks ${ }^{1}$, Robert M.W. Hofstra ${ }^{1}$ ${ }^{6}$, Erwin Brosens ${ }^{1 *}$

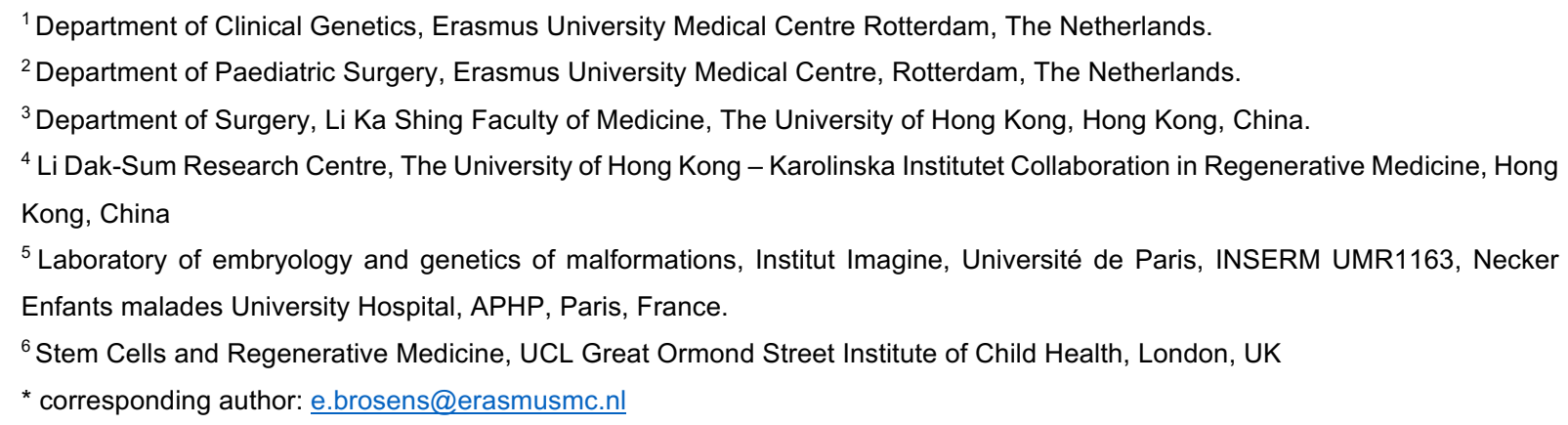

\section{Abstract}

\section{Background}

Hirschsprung disease (HSCR) is characterized by absence of ganglia in the intestine. Approximately $18 \%$ of patients have additional anatomical malformations or neurological symptoms (HSCR-AAM). HSCR is a complex genetic disease in which the loss of enteric ganglia stems from a combination of genetic alterations: rare coding variants, predisposing haplotypes and Copy Number Variation (CNV). Pinpointing the responsible culprits within a large CNV is challenging as often many genes are affected. We investigated if we could find deleterious CNVs and if we could identify the genes responsible for the aganglionosis.

\section{Results}

Deleterious CNVs were detected in three groups of patients: HSCR-AAM, HSCR patients with a confirmed causal genetic variant and HSCR-isolated patients without a known causal variant and controls. Predisposing haplotypes were determined, confirming that every HSCR subgroup had increased contributions of predisposing haplotypes, but their contribution was highest in isolated HSCR patients without RET coding variants. CNV profiling proved that HSCR-AAM patients had larger copy number losses. Gene enrichment strategies using mouse enteric nervous system transcriptomes and constraint metrics were used to determine plausible candidate genes in Copy Number Losses. Validation in zebrafish using CRISPR/Cas9 targeting confirmed the contribution of UFD1L, TBX2, 
medRxiv preprint doi: https://doi.org/10.1101/2020.11.02.20221481; this version posted November 4, 2020. The copyright holder for this preprint (which was not certified by peer review) is the author/funder, who has granted medRxiv a license to display the preprint in It is made available under a CC-BY-NC-ND 4.0 International license.

SLC8A1 and MAPK8 to ENS development. In addition, we revealed epistasis between reduced Ret and Gnl1 expression in vivo.

Conclusion

Rare large Copy Number losses - often de novo - contribute to the disease in HSCR-AAM patients specifically. We proved the involvement of five genes in enteric nervous system development and Hirschsprung disease. 
medRxiv preprint doi: https://doi.org/10.1101/2020.11.02.20221481; this version posted November 4, 2020. The copyright holder for this preprint (which was not certified by peer review) is the author/funder, who has granted medRxiv a license to display the preprint in It is made available under a CC-BY-NC-ND 4.0 International license

\section{Introduction}

Hirschsprung disease (HSCR) is characterized by absence of the enteric nervous system (ENS) in the intestine (aganglionosis). HSCR is a complex genetic disease where the phenotype stems from a combination of genetic alterations: rare coding variants, predisposing haplotypes and Copy Number Variation (CNV)[1]. Most patients have HSCR as an isolated congenital anomaly, while in others the absence of enteric neurons is part of a spectrum of anomalies of a monogenetic syndrome[2]. Approximately $18 \%$ of patients have additional anatomical malformations or neurological symptoms[3] (HSCR-AAM). Deletions of $10 q 11[4,5]$ led to the identification of the REarranged during Transfection gene (RET), the major responsible gene for familial and sporadic isolated HSCR[6, 7]. HSCR penetrance is influenced by predisposing RET risk haplotypes which increase disease risk substantially, especially if homozygous, in specific combinations (rs2506030, rs7069590, rs2435357)[8, 9], together with other risk loci near the semaphorin gene cluster (rs80227144)[9, 10], or the neuregulin 1 gene (NRG1; rs7005606)[11-13].

For many of HSCR-AAM patients the underlying cause is unknown. It is plausible that the associated anomalies in these patients are the result of a pathogenic single nucleotide variant or insertion/deletion. However, all different genomic variation types should be considered, since the presence of unbalanced translocations and CNV has resulted in the identification of causal genes for several syndromes with HSCR as a key feature. For example, deletions of $13 q[1,14-18]$ resulted in the identification of one of the genes responsible for Waardenburg-Shah syndrome type 4 $(E D N R B)[19]$. Deletions of $2 \mathrm{q}[20-23]$ and $4 \mathrm{p}[24]$ contributed to the discovery of genes responsible for Mowatt-Wilson syndrome (ZEB2, formerly ZFHX1B)[25] and the gene responsible for Congenital Central Hypoventilation Syndrome (PHOX2B)[26]. Furthermore, deletions (17q21[27] and 22q11[1, 28]) and duplications (17q23[29], dup22p[27, 30] and 22q11[31]) have been described in HSCR patients. In the light of these findings, we hypothesized that rare CNVs significantly contribute to aganglionosis in HSCR-AAM patients who lack a pathogenic coding variant in any of the known HSCR genes. 
medRxiv preprint doi: https://doi.org/10.1101/2020.11.02.20221481; this version posted November 4, 2020. The copyright holder for this preprint (which was not certified by peer review) is the author/funder, who has granted medRxiv a license to display the preprint in It is made available under a CC-BY-NC-ND 4.0 International license .

\section{Results}

\section{Rare deletions are enriched in HSCR-AAM patients}

Patient and control CNVs were determined and classified as a "rare CNV" when absent from large control cohorts $(n=19,584)$. We also included known pathogenic or modifier CNVs[32, 33]. The size, type and gene content characteristics of rare CNVs were compared to those of 326 controls (Group 4, n=326). With this approach, 56 rare CNVs were detected in 34 HSCR patients (S3). We determined segregation of the rare CNVs in nine patients, five of these were de novo: three gains (22q11.21 - q11.22, 22q11.21 and 7q36.1) and two losses (17q23.1 - q23.2 and 6p22.1 - p21.33). CNV regions did not have a lot of overlap within our cohort, previously published CNV studies or with those described in the DECIPHER (https://decipher.sanger.ac.uk/) database (S3). The number of rare CNVs per individual did not differ between subgroups or controls (S4). However, CNVs found in HSCR-AAM patients (Group 1) were larger compared to controls (Group 4, p=7.297E-6, Figure 2A). This difference is attributed to outliers, large size of losses in specific patients of group $1(p=3.15 E-$ 08)(S5), strongly suggesting a role of these specific CNVs in HSCR-AAM patients.

\section{Candidate genes within a loss are constraint and expressed during ENS development} HSCR disease genes (S6) are often constraint and expressed in the affected tissue, genes within a CNV region associated with HSCR should share these characteristics (Figure 1A). In Group 1, rare CNVs are enriched for ENS genes ( $p=4.565 E-6, S 7)$. Moreover, losses in HSCR-AAM patients (Group 1) contained more ENS genes that are constraint[34, 35], compared to losses found in controls (Group 4, Figure 2B, $p=0,0004$ ). Therefore, constraint genes within $\mathrm{CN}$ losses identified in group 1, and expressed in the ENS were prioritized as candidate genes for HSCR: AKT3, GNL1, GABBR1, SLC8A1, MAPK8, UFD1L, TBX2, USP32 and TUBB (Table 1).

\section{Zebrafish validation confirms the impact of candidate gene disruption on ENS development}

To validate the effect of losing one copy of these constraint genes in ENS development and HSCR, we disrupted their orthologues in zebrafish by CRISPR/Cas 9 targeting. Zebrafish are highly suited for reverse-genetic screening due to their rapid, ex-utero development and transparency and have proven instrumental in the identification of HSCR disease genes[36]. Premature termination of enteric neuron migration was observed in a subgroup of larvae injected with guide RNAs targeting ufd1I $(p=0,0208), t b x 2(p=0,0373)$, slc8a1 $(p=0,0073)$, and mapk8 ( $p=0,0022$, Figure 2D). 
medRxiv preprint doi: https://doi.org/10.1101/2020.11.02.20221481; this version posted November 4, 2020. The copyright holder for this preprint (which was not certified by peer review) is the author/funder, who has granted medRxiv a license to display the preprint in It is made available under a CC-BY-NC-ND 4.0 International license .

\section{HSCR disease coding genetics is heterogeneous}

More evidence for their involvement could be provided by finding additional patients with putative deleterious alterations in genes affected by rare CNV. However, there was no significant enrichment for nonsense, splice site or missense variants in genes impacted by rare gains nor losses (S9) when comparing 443 short segment HSCR patients and 493 controls[37], underlining the genetic heterogeneity between HSCR patients. Nonsense or splice-site variants were detected in eight genes (Table 2). Only one variant, detected in DNA derived from blood and isolated ENS cells, affected a constraint gene overexpressed in the mouse ENS and present in a CN loss: a frameshift (TUBB; NM_001293212.1:c.1330_1331delCAinsA, p.Gln444Serfs*35) in a patient with isolated HSCR (table $1, \mathrm{~S} 8)$.

Copy number loss alone is likely not sufficient to result in HSCR

Considering that aganglionosis has a low prevalence in patients with $22 q 11[32,33,38]$ and $17 q 23[39,40]$ deletions, CNVs alone are probably not sufficient to cause HSCR. HSCR penetrance is influenced by predisposing risk haplotypes [8-13]. Five non-coding risk haplotypes were tested in our three patient groups and compared to an in-house population dataset (group 5) ( $n=727$, Risk noncoding $(\mathrm{RSnc})=2.54)$. As expected, HSCR groups 1, 2 and 3 all had a higher RSnc compared to group $5(p=4.59825 E-14, p=0.000960603, p=1.21875 E-23$, respectively) (Figure $2 C)$, indicating a contribution of the risk haplotypes in all HSCR subgroups. (S10; Figure 1B). Associated common risk haplotypes have epistatic interactions, not only with each other, but also with known HSCR genes such as RET and NRG1[10,12, 41] - and modify HSCR penetrance in monogenetic syndromes and Down syndrome[42-46]. The effect of epistatic interactions is smaller in high penetrant HSCR monogenetic disorders and larger in disorders in which HSCR penetrance is lower[42, 43]. In line with this, contribution of these risk haplotypes was the lowest in group $2(\mathrm{RSnc}=3.70)$, followed by group 1 (RSnc=4.71), and the highest in group $3(\mathrm{RSnc}=5.66)$. Thus, risk haplotypes have indeed a higher impact in HSCR patients without known coding variants, compared to those that contain known coding variants (S11). To model reduced RET expression in patients with predisposing haplotypes, we injected zebrafish with an antisense ATG blocking morpholino specific for ret. Disruption of the candidate genes mapk $8(p=0,011$, Figure $2 \mathrm{E})$ and $g n / 1(p=0,0405$, Figure $2 \mathrm{~F})$ in combination with the ret morpholino resulted in less neurons. Considering that disruption of gnl1 alone did not induce a 
medRxiv preprint doi: https://doi.org/10.1101/2020.11.02.20221481; this version posted November 4, 2020. The copyright holder for this preprint (which was not certified by peer review) is the author/funder, who has granted medRxiv a license to display the preprint in It is made available under a CC-BY-NC-ND 4.0 International license .

HSCR phenotype, these results suggest that only in a sensitized background loss of gnl1 can increase HSCR penetrance.

\section{Candidate genes are associated to ENS development.}

CRISPR/CAS9 targeted knockdown of the candidate genes SLC8A1, GNL1, MAPK8, UFD1L and TBX2 connects these genes to ENS development. These genes are overexpressed in mouse ENS and have associations to ENS development. For instance, Mitogen-Activated Protein Kinase 8 gene (MAPK8) is part of the Mitogen activated protein (MAP) kinase pathway and required for ENCCs to migrate properly[47]. UFD1L, as this encodes for a downstream target of HAND2[48]. Hand2-- mice have decreased numbers of enteric neurons, neuronal differentiation defects and a disorganized ENS[49, 50]. T-Box 2 (TBX2) codes for a transcription factor already known to be involved in the regulation of neural crest derived melanocytes[51], a process that is also hampered in specific HSCR patients carrying pathogenic variants in $E D N 3, \operatorname{SOX} 10$ and $E D N R B[52,53]$. Candidate genes are discussed further in S8.

\section{Discussion}

The results presented here highlight the importance of Copy Number profiling, leading us to propose a HSCR risk model that consists of risk scores for: rare coding variants, non-coding variants, rare CNVs and currently unknown risk factors (e.g. epigenetic modifications and perhaps environmental factors). Considering HSCR-AAM (group 1), 36\% of patients have contained a CNV harboring genes overexpressed in the mouse ENS (Figure 3A). Our risk model (Figure 3C) indicates major contributing factors in each group: in group $1 \mathrm{CNVs}$, in group 2 coding variants and in group 3 noncoding variants (Figure 3A, C). The predisposing RET haplotypes reduce RET expression[54] and in combination with the other risk haplotypes increase HSCR risk substantially. Translating this population risk to a threshold for HSCR development in individual patients is challenging as it is not precisely known how many of (and if) these known predisposing haplotypes are sufficient to result in aganglionosis. If we set a threshold at a relatively high level (RSnc>6), this would explain HSCR in $30 \%$ of patients in group 3 (S11, Figure 2C, 3A). Most HSCR-AAM patients have a lower RSnc, which makes sense, as this group contains more high impact CNVs and whilst they lack RET coding variants, they potentially have variants in other genes (Figure 2C, 3A, S11). Translating our findings back to our full cohort including all patients seen by a clinical geneticist and screened for RET 
medRxiv preprint doi: https://doi.org/10.1101/2020.11.02.20221481; this version posted November 4, 2020. The copyright holder for this preprint (which was not certified by peer review) is the author/funder, who has granted medRxiv a license to display the preprint in It is made available under a CC-BY-NC-ND 4.0 International license .

155

156

157

158

159

160

161

162

163

164

165

mutations, HSCR coding variants explain $21 \%$ of HSCR cases (Figure 3B). If we consider CNVs containing genes expressed in the ENS, we could explain an additional 10\% (Figure 3B). Importantly, this is an underestimation, since for $55 \%$ of patients without a $R E T$ coding variant no copy number profiling is performed (Figure 3B) and we focussed exclusively on rare CNVs. Since more common CNVs can also modify HSCR penetrance[55, 56], our results emphasize the need for a more widespread genomic analyses in all subgroups. Noncoding risk scores could be one of the determinants for a more elaborate genetic evaluation. A high noncoding risk score in a HSCR patient without associated anomalies is less likely to have a deleterious RET coding variant, patients with a low score are more likely to benefit from exome sequencing. Similarly, patients with large de novo losses often have a more complex phenotype and more intensive clinical investigations might be indicated.

\section{Conclusions}

To summarize, HSCR genetics is complex with contributions of predisposing haplotypes in all HSCR subgroups. Rare large CNVs - often de novo (S5) - contribute substantially to the disease in HSCR-AAM patients. These CNVs are enriched for CN losses and for genes intolerant to variation that are overexpressed in the developing mouse ENS. Disruption of some of these genes in zebrafish confirmed that reduced expression of these genes increased the occurrence of HSCR, alone, or in epistasis with Ret. These genes have functional overlap with known HSCR disease genes: e.g. UFD1L is involved signalling receptor binding and MAPK8 in axon guidance. Our "ENS expressed gene" based approach lead to the identification of new HSCR disease genes (Figure 3; Table 2): UFD1L, TBX2, SLC8A1, GNL1 and MAPK8.

\section{Materials and methods}

All authors had access to the study data and reviewed and approved the final manuscript

\section{Patient inclusion}

This project was approved by the Medical ethics committee of the Erasmus Medical Centre (Hirschsprung disease: no 2012-582, addendum No. 1 and no.193.948/2000/159, addendum No. 1 and 2, MEC-20122387). We selected 58 out of 197 patients (Figure 3) for which DNA and informed consent were available, and in whom RET was screened. Three subgroups of HSCR patients were 
medRxiv preprint doi: https://doi.org/10.1101/2020.11.02.20221481; this version posted November 4, 2020. The copyright holder for this preprint (which was not certified by peer review) is the author/funder, who has granted medRxiv a license to display the preprint in

It is made available under a CC-BY-NC-ND 4.0 International license .

183

184

185

186

187

188

189

190

191

192

193

194

195

196

197

198

199

200

201

202

203

204

205

206

207

included in the CNV detection study: patients with HSCR and additional anatomical malformations or neurological defects, but without a RET pathogenic variant, or other causal genetic defect (group 1, $\mathrm{n}=23, \mathrm{~S} 1$ ), patients with HSCR and a known variant in RET or another causal gene (group 2, $\mathrm{n}=15$, S2), and patients with only HSCR, without a deleterious RET coding variant or other causal genetic defect (group 3, n=20). Additionally, we included unaffected control individuals (group 4, n=326). Genotypes of noncoding predisposing loci were compared with those of other unaffected controls (group 5, $\mathrm{n}=727$ ).

\section{Determination of Copy Number Variation (Figure 1a)}

CNV profiles were determined with either the HumanCytoSNP-12 v2.1 or the Infinium Global Screening Array-24 v1.0 (Illumina Inc., San Diego, CA, USA), using methods previously described[57]. CNV profiles were inspected visually in Biodiscovery Nexus CN8.0 (Biodiscovery Inc., Hawthorne, CA, USA). CNVs with an overlap of at least $75 \%$ with similar state $\mathrm{CN}$ changes, were either classified as rare, when absent from large control cohorts $(n=19,584)$, or as a known modifier[32, 33]. CNV number, size, type and gene content of rare CNVs were determined in HSCR patients $(n=58)$ and unaffected controls $(n=326)$ and compared between the control groups and previously described HSCR subgroups. All rare CNVs were uploaded to the ClinVar database (https://www.ncbi.nlm.nih.gov/clinvar/) and are depicted in S3.

\section{Exclusion of the involvement of known disease genes (Figure 1a)}

The presence of $R E T$ coding mutations and those in intron-exon boundaries, in all patients in this study are determined. Furthermore, if a specific monogenetic syndrome (S6) was suspected based on the phenotypic spectrum observed, the suspected gene(s) were evaluated using a targeted NGS panel or whole exome sequencing. In four HSCR patients with associated anomalies (Group 1) and nine HSCR patients without associated anomalies (Group 3), the involvement of other known disease genes was excluded[2, 36, 37, 58] using whole exome sequencing (WES) with previously described pipelines[59, 60] and variant prioritization methods[61].

\section{Evaluation of candidate gene expression (Figure 1a)}

We prioritized candidate genes based on gene characteristics: genes that are intolerant to variation and/or dosage sensitive (see variant filter criteria), and overexpressed in the developing mouse ENS compared to whole gut, between embryonic day E11.5 and E15.5 [62, 63]. Since data from human 
medRxiv preprint doi: https://doi.org/10.1101/2020.11.02.20221481; this version posted November 4, 2020. The copyright holder for this preprint (which was not certified by peer review) is the author/funder, who has granted medRxiv a license to display the preprint in

It is made available under a CC-BY-NC-ND 4.0 International license .

212

213

214

215

216

217

218

219

220

221

222

223

224

225

226

227

228

colon was only available for embryonic week 12, 14 and 16, we evaluated gene expression in these time points[64]. Data was downloaded from the gene expression omnibus (GSE34208 and GSE100130). Genes that were dosage sensitive, and either overexpressed in the mouse ENS or highly expressed in human embryonic colon, were selected.

\section{Variant prioritization in loss of function genes (Figure 1a)}

To determine whether a gene affected by a rare putative deleterious CNV was constraint[34, 35], we allowed some tolerance to account for reduced penetrance (S9). Variants from NGS data previously generated were prioritized according to settings described in S9: These data included a WES cohort of sporadic HSCR ( $n=76,149$ controls) and (2) a Whole Genome Sequencing (WGS) cohort of 443 short segment HSCR patients and 493 unaffected controls[37]. Using RVTESTS[65], a variant burden test was done comparing the variant burden in 443 short segment HSCR patients and 493 controls (S9). All rare putative deleterious loss of function variants unique to the HSCR cohort in constraint genes are described in table 1.

\section{Genotyping of HSCR associated SNPs}

Sanger sequencing was used to genotype all patients for SNPs known to be associated to HSCR[810, 55]. Primer sequences can be found in S11. We used (proxy) SNPs present on the GSAMD-v1 chip to determine the Rotterdam population background for these risk haplotypes (S10).

\section{Experimental animals}

Zebrafish were kept on a $14 \mathrm{~h} / 10 \mathrm{~h}$ light-dark cycle at $28^{\circ} \mathrm{C}$, during development and adulthood.

$\operatorname{Tg}($ phox2bb:GFP) animals were used for all experiments[66]. Larvae were kept in HEPES-buffered E3 medium and 0.003\% 1-phenyl 2-thiourea (PTU) was added 24 hours post fertilization (hpf), to prevent pigmentation.

\section{CRISPR/Cas9 gene disruption}

Gene targeting using CRISPR/Cas9 was performed as described previously[67]. The Alt-R CRISPRCas9 System from Intergrated DNA Technologies (IDT) was used[68] (Figure 2A). crRNAs were designed using the IDT tool and selected on high target efficiency and low off target effect. gRNA sequences are listed in S13, primers used are listed in supplementary S14. Efficiency of indel generation was determined as described previously[67] (S15). 
medRxiv preprint doi: https://doi.org/10.1101/2020.11.02.20221481; this version posted November 4, 2020. The copyright holder for this preprint (which was not certified by peer review) is the author/funder, who has granted medRxiv a license to display the preprint in It is made available under a CC-BY-NC-ND 4.0 International license .

\section{Morpholino injections}

Fertilized zebrafish eggs were injected with the CRISPR/Cas9 complex. Subsequently, 0,5 or $1 \mathrm{ng}$ of translation blocking morpholino against ret (5'- ACACGATTCCCCGCGTACTTCCCAT -3'), and 1:10 Phenol Red (Sigma-Aldrich), was injected between the 1- and 4-cell stage (see figure 2D)[69]. To minimize variability, the same needle was used to inject the controls, that were not injected with CRISPR/Cas9 complex.

\section{Imaging}

Images of $5 \mathrm{dpf} \operatorname{tg}$ (phox2bb:GFP) larvae were taken using a Leica M165 fluorescent dissection microscope with the Leica LASX software. Larvae were anesthetized with 0.016\% MS-222 in HEPES buffered E3 medium and positioned on their lateral side on a $1.5-2 \%$ agarose coated petridish, to enable visualization of the enteric neurons.

\section{Scoring HSCR phenotypes in zebrafish}

To determine whether the larvae present with a HSCR phenotype five categories were made: normal, hypoganglionic (less neurons), ultra-short segment HSCR (only most distal end of the gut lack neurons), short segment HSCR (neurons colonize until the midgut), and total colonic HSCR (neurons are absent from the total intestine) (see figure $2 \mathrm{C}$ ).

\section{Statistical analysis}

The number and size of rare CNVs, the number of rare losses and gains, the number of genes intolerant to variation (SNVs and CNVs), the number of genes overexpressed in mouse ENS per rare $\mathrm{CNV}$, and the relative weighted risk score, were determined and compared for the different groups with a single ANOVA test. If group differences existed $(P<0.05)$, we determined which subgroups were significantly different, using a two-tailed T-test. For statistical analysis of the zebrafish experiments the online tool MedCalc (MedCalc software Itd., Ostend, Belgium), was used together with the "N-1" Chisquared test, number of larvae used and $p$ values can be found in supplementary S16.

\section{Supplemental Data description}

CNV_HSCR_MedRxiv_Kuil_etal_supplement contains 16 elements including detailed patients descriptions, additional results, extended methods, primers and gRNA sequences. 
medRxiv preprint doi: https://doi.org/10.1101/2020.11.02.20221481; this version posted November 4, 2020. The copyright holder for this preprint (which was not certified by peer review) is the author/funder, who has granted medRxiv a license to display the preprint in It is made available under a CC-BY-NC-ND 4.0 International license.

268 Guarantor of the article [EB]; Conception or design of the work [EB, $A B, R H]$, the acquisition [RW, JW,

$269 \mathrm{TL}, \mathrm{RH}, \mathrm{YB}, \mathrm{CS}, \mathrm{CM}, \mathrm{DT}, \mathrm{LK}]$, analysis [LK, KM, CT, BM, AK], or interpretation [EB, LK, CT] of data;

270 drafted the work [EB, KM, LK] or substantively revised it [MA, RH, AB, JA, SL, MB, PT].

\section{Acknowledgements}

272 This study makes use of data generated by the DECIPHER community[70]. A full list of centers who

273 contributed to the generation of the data is available from $\mathrm{http}: / /$ decipher.sanger.ac.uk and via email

274 from decipher@sanger.ac.uk. 
medRxiv preprint doi: https://doi.org/10.1101/2020.11.02.20221481; this version posted November 4, 2020. The copyright holder for this preprint (which was not certified by peer review) is the author/funder, who has granted medRxiv a license to display the preprint in perpetuity.

It is made available under a CC-BY-NC-ND 4.0 International license.

\section{References}

1. Tilghman JM, Ling AY, Turner TN, Sosa MX, Krumm N, Chatterjee S, et al. Molecular Genetic Anatomy and Risk Profile of Hirschsprung's Disease. N Engl J Med. 2019;380(15):1421-32. PubMed PMID: 30970187.

2. Alves MM, Sribudiani Y, Brouwer RW, Amiel J, Antinolo G, Borrego S, et al. Contribution of rare and common variants determine complex diseases-Hirschsprung disease as a model. Dev Biol. 2013;382(1):320-9. Epub 2013/05/28. doi: 10.1016/j.ydbio.2013.05.019. PubMed PMID: 23707863. 3. Amiel J, Sproat-Emison E, Garcia-Barcelo M, Lantieri F, Burzynski G, Borrego S, et al. Hirschsprung disease, associated syndromes and genetics: a review. J Med Genet. 2008;45(1):1-14. PubMed PMID: 17965226.

4. Fewtrell MS, Tam PK, Thomson AH, Fitchett M, Currie J, Huson SM, et al. Hirschsprung's disease associated with a deletion of chromosome 10 (q11.2q21.2): a further link with the neurocristopathies? J Med Genet. 1994;31(4):325-7. PubMed PMID: 7915329.

5. Martucciello G, Bicocchi MP, Dodero P, Lerone M, Silengo Cirillo M, Puliti A, et al. Total colonic aganglionosis associated with interstitial deletion of the long arm of chromosome 10. Pediatric Surgery International. 1992;7(4):308-10. doi: 10.1007/bf00183991.

6. $\quad$ Edery P, Lyonnet S, Mulligan LM, Pelet A, Dow E, Abel L, et al. Mutations of the RET protooncogene in Hirschsprung's disease. Nature. 1994;367(6461):378-80. PubMed PMID: 8114939.

7. Romeo G, Ronchetto P, Luo Y, Barone V, Seri M, Ceccherini I, et al. Point mutations affecting the tyrosine kinase domain of the RET proto-oncogene in Hirschsprung's disease. Nature. 1994;367(6461):377-8. PubMed PMID: 8114938.

8. Chatterjee S, Kapoor A, Akiyama JA, Auer DR, Lee D, Gabriel S, et al. Enhancer Variants Synergistically Drive Dysfunction of a Gene Regulatory Network In Hirschsprung Disease. Cell. 2016;167(2):355-68.e10. Epub 2016/10/04. doi: 10.1016/j.cell.2016.09.005. PubMed PMID: 27693352; PubMed Central PMCID: PMCPMC5113733.

9. Kapoor A, Jiang Q, Chatterjee S, Chakraborty P, Sosa MX, Berrios C, et al. Population variation in total genetic risk of Hirschsprung disease from common RET, SEMA3 and NRG1 susceptibility polymorphisms. Human molecular genetics. 2015;24(10):2997-3003. Epub 2015/02/11. doi: 10.1093/hmg/ddv051. PubMed PMID: 25666438; PubMed Central PMCID: PMCPMC4406299. 10. Jiang Q, Arnold S, Heanue T, Kilambi KP, Doan B, Kapoor A, et al. Functional loss of semaphorin $3 C$ and/or semaphorin $3 D$ and their epistatic interaction with ret are critical to Hirschsprung disease liability. Am J Hum Genet. 2015;96(4):581-96. Epub 2015/04/04. doi: 10.1016/j.ajhg.2015.02.014. PubMed PMID: 25839327; PubMed Central PMCID: PMCPMC4385176. 11. Garcia-Barcelo MM, Tang CS, Ngan ES, Lui VC, Chen Y, So MT, et al. Genome-wide association study identifies NRG1 as a susceptibility locus for Hirschsprung's disease. Proc Natl Acad Sci U S A. 2009;106(8):2694-9. Epub 2009/02/07. doi: 10.1073/pnas.0809630105. PubMed PMID: 19196962; PubMed Central PMCID: PMCPMC2650328.

12. Gui H, Tang WK, So MT, Proitsi P, Sham PC, Tam PK, et al. RET and NRG1 interplay in Hirschsprung disease. Hum Genet. 2013;132(5):591-600. Epub 2013/02/13. doi: 10.1007/s00439-0131272-9. PubMed PMID: 23400839.

13. Tang CS, Tang WK, So MT, Miao XP, Leung BM, Yip BH, et al. Fine mapping of the NRG1 Hirschsprung's disease locus. PLoS One. 2011;6(1):e16181. Epub 2011/02/02. doi: 10.1371/journal.pone.0016181. PubMed PMID: 21283760; PubMed Central PMCID: PMCPMC3024406.

14. Bottani A, Xie YG, Binkert F, Schinzel A. A case of Hirschsprung disease with a chromosome 13 microdeletion, del(13)(q32.3q33.2): potential mapping of one disease locus. Hum Genet. 1991;87(6):748-50. PubMed PMID: 1937482.

15. Kiss P, Osztovics M. Association of $13 q$ deletion and Hirschsprung's disease. J Med Genet. 1989;26(12):793-4. PubMed PMID: 2614805.

16. Lamont MA, Fitchett M, Dennis NR. Interstitial deletion of distal $13 q$ associated with Hirschsprung's disease. J Med Genet. 1989;26(2):100-4. PubMed PMID: 2918536.

17. Shanske A, Ferreira JC, Leonard JC, Fuller P, Marion RW. Hirschsprung disease in an infant with a contiguous gene syndrome of chromosome 13. Am J Med Genet. 2001;102(3):231-6. PubMed PMID: 11484199.

18. Sparkes RS, Sparkes MC, Kalina RE, Pagon RA, Salk DJ, Disteche CM. Separation of retinoblastoma and esterase $D$ loci in a patient with sporadic retinoblastoma and del(13)(q14.1q22.3). Hum Genet. 1984;68(3):258-9. PubMed PMID: 6500578. 
medRxiv preprint doi: https://doi.org/10.1101/2020.11.02.20221481; this version posted November 4, 2020. The copyright holder for this preprint (which was not certified by peer review) is the author/funder, who has granted medRxiv a license to display the preprint in perpetuity.

It is made available under a CC-BY-NC-ND 4.0 International license.

19. Puffenberger EG, Hosoda K, Washington SS, Nakao K, deWit D, Yanagisawa M, et al. A missense mutation of the endothelin-B receptor gene in multigenic Hirschsprung's disease. Cell. 1994;79(7):1257-66. Epub 1994/12/30. PubMed PMID: 8001158.

20. Amiel J, Espinosa-Parrilla Y, Steffann J, Gosset P, Pelet A, Prieur M, et al. Large-scale deletions and SMADIP1 truncating mutations in syndromic Hirschsprung disease with involvement of midline structures. Am J Hum Genet. 2001;69(6):1370-7. PubMed PMID: 11595972.

21. Lurie IW, Supovitz KR, Rosenblum-Vos LS, Wulfsberg EA. Phenotypic variability of del(2) (q22-q23): report of a case with a review of the literature. Genet Couns. 1994;5(1):11-4. PubMed PMID: 8031530.

22. McMilin KD, Reiss JA, Brown MG, Black MH, Buckmaster DA, Durum CT, et al. Clinical outcomes of four patients with microdeletion in the long arm of chromosome 2. Am J Med Genet. 1998;78(1):36-43. PubMed PMID: 9637421.

23. Mowat DR, Croaker GD, Cass DT, Kerr BA, Chaitow J, Ades LC, et al. Hirschsprung disease, microcephaly, mental retardation, and characteristic facial features: delineation of a new syndrome and identification of a locus at chromosome 2q22-q23. J Med Genet. 1998;35(8):617-23. PubMed PMID: 9719364.

24. Benailly HK, Lapierre JM, Laudier B, Amiel J, Attie T, De Blois MC, et al. PMX2B, a new candidate gene for Hirschsprung's disease. Clin Genet. 2003;64(3):204-9. PubMed PMID: 12919134. 25. Wakamatsu N, Yamada Y, Yamada K, Ono T, Nomura N, Taniguchi H, et al. Mutations in SIP1, encoding Smad interacting protein-1, cause a form of Hirschsprung disease. Nat Genet. 2001;27(4):369-70. Epub 2001/03/30. doi: 10.1038/86860. PubMed PMID: 11279515. 26. Amiel J, Laudier B, Attie-Bitach T, Trang H, de Pontual L, Gener B, et al. Polyalanine expansion and frameshift mutations of the paired-like homeobox gene PHOX2B in congenital central hypoventilation syndrome. Nat Genet. 2003;33(4):459-61. Epub 2003/03/18. doi: 10.1038/ng1130. PubMed PMID: 12640453.

27. Amiel J, Lyonnet S. Hirschsprung disease, associated syndromes, and genetics: a review. J Med Genet. 2001;38(11):729-39. PubMed PMID: 11694544.

28. Brewer C, Holloway S, Zawalnyski P, Schinzel A, FitzPatrick D. A chromosomal deletion map of human malformations. Am J Hum Genet. 1998;63(4):1153-9. PubMed PMID: 9758599.

29. Brewer C, Holloway S, Zawalnyski P, Schinzel A, FitzPatrick D. A chromosomal duplication map of malformations: regions of suspected haplo- and triplolethality--and tolerance of segmental aneuploidy--in humans. Am J Hum Genet. 1999;64(6):1702-8. PubMed PMID: 10330358.

30. Mahboubi S, Templeton JM, Jr. Association of Hirschsprung's disease and imperforate anus in a patient with "cat-eye" syndrome. A report of one case and review of the literature. Pediatr Radiol. 1984;14(6):441-2. PubMed PMID: 6504608.

31. Kerstjens-Frederikse WS, Hofstra RM, van Essen AJ, Meijers JH, Buys $\mathrm{CH}$. A Hirschsprung disease locus at 22q11? J Med Genet. 1999;36(3):221-4. PubMed PMID: 10204849.

32. Coe BP, Witherspoon K, Rosenfeld JA, van Bon BW, Vulto-van Silfhout AT, Bosco P, et al. Refining analyses of copy number variation identifies specific genes associated with developmental delay. Nat Genet. 2014;46(10):1063-71. PubMed PMID: 25217958.

33. Cooper GM, Coe BP, Girirajan S, Rosenfeld JA, Vu TH, Baker C, et al. A copy number variation morbidity map of developmental delay. Nat Genet. 2011;43(9):838-46. PubMed PMID: 21841781.

34. Lek M, Karczewski KJ, Minikel EV, Samocha KE, Banks E, Fennell T, et al. Analysis of protein-coding genetic variation in 60,706 humans. Nature. 2016;536(7616):285-91. PubMed PMID: 27535533.

35. Ruderfer DM, Hamamsy T, Lek M, Karczewski KJ, Kavanagh D, Samocha KE, et al. Patterns of genic intolerance of rare copy number variation in 59,898 human exomes. Nat Genet. 2016;48(10):1107-11. Epub 2016/08/18. doi: 10.1038/ng.3638. PubMed PMID: 27533299; PubMed Central PMCID: PMCPMC5042837.

36. Gui H, Schriemer D, Cheng WW, Chauhan RK, Antinolo G, Berrios C, et al. Whole exome sequencing coupled with unbiased functional analysis reveals new Hirschsprung disease genes. Genome Biol. 2017;18(1):48. Epub 2017/03/10. doi: 10.1186/s13059-017-1174-6

10.1186/s13059-017-1174-6 [pii]. PubMed PMID: 28274275; PubMed Central PMCID: PMC5343413. 37. Tang CS, Li P, Lai FP, Fu AX, Lau ST, So MT, et al. Identification of Genes Associated With Hirschsprung Disease, Based on Whole-Genome Sequence Analysis, and Potential Effects on Enteric Nervous System Development. Gastroenterology. 2018;155(6):1908-22.e5. Epub 2018/09/16. doi: 10.1053/j.gastro.2018.09.012. PubMed PMID: 30217742. 
medRxiv preprint doi: https://doi.org/10.1101/2020.11.02.20221481; this version posted November 4, 2020. The copyright holder for this preprint (which was not certified by peer review) is the author/funder, who has granted medRxiv a license to display the preprint in perpetuity.

It is made available under a CC-BY-NC-ND 4.0 International license.

38. Rosenfeld JA, Coe BP, Eichler EE, Cuckle H, Shaffer LG. Estimates of penetrance for recurrent pathogenic copy-number variations. Genet Med. 2013;15(6):478-81. Epub 2012/12/22. doi: 10.1038/gim.2012.164. PubMed PMID: 23258348; PubMed Central PMCID: PMCPMC3664238. 39. Ballif BC, Theisen A, Rosenfeld JA, Traylor RN, Gastier-Foster J, Thrush DL, et al. Identification of a recurrent microdeletion at 17q23.1q23.2 flanked by segmental duplications associated with heart defects and limb abnormalities. Am J Hum Genet. 2010;86(3):454-61. PubMed PMID: 20206336.

40. Laurell T, Lundin J, Anderlid BM, Gorski JL, Grigelioniene G, Knight SJ, et al. Molecular and clinical delineation of the 17q22 microdeletion phenotype. Eur J Hum Genet. 2013;21(10):1085-92. PubMed PMID: 23361222.

41. Tang CS, Gui H, Kapoor A, Kim JH, Luzon-Toro B, Pelet A, et al. Trans-ethnic meta-analysis of genome-wide association studies for Hirschsprung disease. Human molecular genetics. 2016;25(23):5265-75. Epub 2016/10/06. doi: 10.1093/hmg/ddw333. PubMed PMID: 27702942. 42. de Pontual L, Pelet A, Trochet D, Jaubert F, Espinosa-Parrilla Y, Munnich A, et al. Mutations of the RET gene in isolated and syndromic Hirschsprung's disease in human disclose major and modifier alleles at a single locus. J Med Genet. 2006;43(5):419-23. Epub 2006/01/31. doi: 10.1136/jmg.2005.040113. PubMed PMID: 16443855; PubMed Central PMCID: PMCPMC2649010. 43. de Pontual L, Pelet A, Clement-Ziza M, Trochet D, Antonarakis SE, Attie-Bitach T, et al. Epistatic interactions with a common hypomorphic RET allele in syndromic Hirschsprung disease. Hum Mutat. 2007;28(8):790-6. Epub 2007/04/03. doi: 10.1002/humu.20517. PubMed PMID: 17397038.

44. de Pontual L, Zaghloul NA, Thomas S, Davis EE, McGaughey DM, Dollfus H, et al. Epistasis between RET and BBS mutations modulates enteric innervation and causes syndromic Hirschsprung disease. Proc Natl Acad Sci U S A. 2009;106(33):13921-6. Epub 2009/08/12. doi:

10.1073/pnas.0901219106. PubMed PMID: 19666486; PubMed Central PMCID: PMCPMC2728996. 45. Arnold S, Pelet A, Amiel J, Borrego S, Hofstra R, Tam P, et al. Interaction between a chromosome 10 RET enhancer and chromosome 21 in the Down syndrome-Hirschsprung disease association. Hum Mutat. 2009;30(5):771-5. Epub 2009/03/24. doi: 10.1002/humu.20944. PubMed PMID: 19306335; PubMed Central PMCID: PMCPMC2779545.

46. Jannot AS, Pelet A, Henrion-Caude A, Chaoui A, Masse-Morel M, Arnold S, et al. Chromosome 21 scan in Down syndrome reveals DSCAM as a predisposing locus in Hirschsprung disease. PLoS One. 2013;8(5):e62519. Epub 2013/05/15. doi: 10.1371/journal.pone.0062519. PubMed PMID: 23671607; PubMed Central PMCID: PMCPMC3646051. 47. Natarajan D, Marcos-Gutierrez C, Pachnis V, de Graaff E. Requirement of signalling by receptor tyrosine kinase RET for the directed migration of enteric nervous system progenitor cells during mammalian embryogenesis. Development. 2002;129(22):5151-60. Epub 2002/10/26. PubMed PMID: 12399307.

48. Yamagishi H, Garg V, Matsuoka R, Thomas T, Srivastava D. A molecular pathway revealing a genetic basis for human cardiac and craniofacial defects. Science. 1999;283(5405):1158-61. PubMed PMID: 10024240.

49. Hendershot TJ, Liu H, Sarkar AA, Giovannucci DR, Clouthier DE, Abe M, et al. Expression of Hand2 is sufficient for neurogenesis and cell type-specific gene expression in the enteric nervous system. Dev Dyn. 2007;236(1):93-105. PubMed PMID: 17075884.

50. D'Autreaux F, Margolis KG, Roberts J, Stevanovic K, Mawe G, Li Z, et al. Expression level of Hand2 affects specification of enteric neurons and gastrointestinal function in mice. Gastroenterology. 2011;141(2):576-87, 87 e1-6. PubMed PMID: 21669203.

51. Pan L, Ma X, Wen B, Su Z, Zheng X, Liu Y, et al. Microphthalmia-associated transcription factor/T-box factor-2 axis acts through Cyclin D1 to regulate melanocyte proliferation. Cell Prolif. 2015;48(6):631-42. Epub 2015/10/22. doi: 10.1111/cpr.12227. PubMed PMID: 26486273. 52. Stanchina L, Baral V, Robert F, Pingault V, Lemort N, Pachnis V, et al. Interactions between Sox10, Edn3 and Ednrb during enteric nervous system and melanocyte development. Dev Biol. 2006;295(1):232-49. Epub 2006/05/03. doi: 10.1016/j.ydbio.2006.03.031. PubMed PMID: 16650841. 53. Watanabe Y, Stanchina L, Lecerf L, Gacem N, Conidi A, Baral V, et al. Differentiation of Mouse Enteric Nervous System Progenitor Cells Is Controlled by Endothelin 3 and Requires Regulation of Ednrb by SOX10 and ZEB2. Gastroenterology. 2017;152(5):1139-50.e4. Epub 2017/01/09. doi: 10.1053/j.gastro.2016.12.034. PubMed PMID: 28063956.

54. Miao X, Leon TY, Ngan ES, So MT, Yuan ZW, Lui VC, et al. Reduced RET expression in gut tissue of individuals carrying risk alleles of Hirschsprung's disease. Human molecular genetics. 2010;19(8):1461-7. Epub 2010/01/22. doi: 10.1093/hmg/ddq020. PubMed PMID: 20089534. 
medRxiv preprint doi: https://doi.org/10.1101/2020.11.02.20221481; this version posted November 4, 2020. The copyright holder for this preprint (which was not certified by peer review) is the author/funder, who has granted medRxiv a license to display the preprint in perpetuity.

It is made available under a CC-BY-NC-ND 4.0 International license .

55. Jiang Q, Ho YY, Hao L, Nichols Berrios C, Chakravarti A. Copy number variants in candidate genes are genetic modifiers of Hirschsprung disease. PLoS One. 2011;6(6):e21219. Epub 2011/06/30. doi: 10.1371/journal.pone.0021219. PubMed PMID: 21712996; PubMed Central PMCID: PMCPMC3119685.

56. Tang CS, Cheng G, So MT, Yip BH, Miao XP, Wong EH, et al. Genome-wide copy number analysis uncovers a new HSCR gene: NRG3. PLoS Genet. 2012;8(5):e1002687. Epub 2012/05/17. doi: 10.1371/journal.pgen.1002687. PubMed PMID: 22589734; PubMed Central PMCID: PMCPMC3349728.

57. Brosens E, Marsch F, de Jong EM, Zaveri HP, Hilger AC, Choinitzki VG, et al. Copy number variations in 375 patients with oesophageal atresia and/or tracheoesophageal fistula. Eur J Hum Genet. 2016;24(12):1715-23. PubMed PMID: 27436264.

58. Lai FP, Lau ST, Wong JK, Gui H, Wang RX, Zhou T, et al. Correction of HirschsprungAssociated Mutations in Human Induced Pluripotent Stem Cells Via Clustered Regularly Interspaced Short Palindromic Repeats/Cas9, Restores Neural Crest Cell Function. Gastroenterology. 2017;153(1):139-53 e8. doi: 10.1053/j.gastro.2017.03.014. PubMed PMID: 28342760.

59. Brouwer RWW, van den Hout M, Kockx CEM, Brosens E, Eussen B, de Klein A, et al. Nimbus: A design-driven analyses suite for amplicon based NGS data. Bioinformatics. 2018. Epub 2018/03/15. doi: 10.1093/bioinformatics/bty145. PubMed PMID: 29538618.

60. Brouwer RW, van den Hout MC, Grosveld FG, van ljcken WF. NARWHAL, a primary analysis pipeline for NGS data. Bioinformatics. 2012;28(2):284-5. Epub 2011/11/11. doi: 10.1093/bioinformatics/btr613. PubMed PMID: 22072383.

61. Halim D, Brosens E, Muller F, Wangler MF, Beaudet AL, Lupski JR, et al. Loss-of-Function Variants in MYLK Cause Recessive Megacystis Microcolon Intestinal Hypoperistalsis Syndrome. Am J Hum Genet. 2017;101(1):123-9. Epub 2017/06/13. doi: 10.1016/j.ajhg.2017.05.011. PubMed PMID: 28602422; PubMed Central PMCID: PMCPMC5501771.

62. Schriemer D, Sribudiani Y, A IJ, Natarajan D, MacKenzie KC, Metzger M, et al. Regulators of gene expression in Enteric Neural Crest Cells are putative Hirschsprung disease genes. Dev Biol. 2016;416(1):255-65. PubMed PMID: 27266404.

63. Memic F, Knoflach V, Morarach K, Sadler R, Laranjeira C, Hjerling-Leffler J, et al. Transcription and Signaling Regulators in Developing Neuronal Subtypes of Mouse and Human Enteric Nervous System. Gastroenterology. 2018;154(3):624-36. PubMed PMID: 29031500. 64. McCann CJ, Alves MM, Brosens E, Natarajan D, Perin S, Chapman C, et al. Neuronal Development and Onset of Electrical Activity in the Human Enteric Nervous System.

Gastroenterology. 2019. Epub 2019/01/06. doi: 10.1053/j.gastro.2018.12.020. PubMed PMID: 30610864.

65. Zhan X, Hu Y, Li B, Abecasis GR, Liu DJ. RVTESTS: an efficient and comprehensive tool for rare variant association analysis using sequence data. Bioinformatics. 2016;32(9):1423-6. PubMed PMID: 27153000.

66. Nechiporuk A, Linbo T, Poss KD, Raible DW. Specification of epibranchial placodes in zebrafish. Development. 2007;134(3):611-23. PubMed PMID: 17215310.

67. Kuil LE, Oosterhof N, Geurts SN, van der Linde HC, Meijering E, van Ham TJ. Reverse genetic screen reveals that II34 facilitates yolk sac macrophage distribution and seeding of the brain. Dis Model Mech. 2019;12(3). PubMed PMID: 30765415.

68. Hoshijima K, Jurynec MJ, Klatt Shaw D, Jacobi AM, Behlke MA, Grunwald DJ. Highly Efficient CRISPR-Cas9-Based Methods for Generating Deletion Mutations and F0 Embryos that Lack Gene Function in Zebrafish. Dev Cell. 2019;51(5):645-57 e4. PubMed PMID: 31708433.

69. Heanue TA, Pachnis V. Ret isoform function and marker gene expression in the enteric nervous system is conserved across diverse vertebrate species. Mech Dev. 2008;125(8):687-99. PubMed PMID: 18565740.

70. Firth HV, Richards SM, Bevan AP, Clayton S, Corpas M, Rajan D, et al. DECIPHER: Database of Chromosomal Imbalance and Phenotype in Humans Using Ensembl Resources. Am J Hum Genet. 2009;84(4):524-33. PubMed PMID: 19344873. 
medRxiv preprint doi: https://doi.org/10.1101/2020.11.02.20221481; this version posted November 4, 2020. The copyright holder for this preprint (which was not certified by peer review) is the author/funder, who has granted medRxiv a license to display the preprint in It is made available under a CC-BY-NC-ND 4.0 International license

Figure legends

503

504

505

506

507

508

509

510

Figure 1. Schematic overview of our overall study design and methods used. a) In brief: We determined the Copy Number profiles of different subgroups of HSCR patients (1-3) and controls (4). We determined RET and / or known disease gene coding mutations and ranked the genes affected by a CNV according to frequency in controls, expression in the developing mouse ENS and gene tolerance to variation. Next, we determined whether disruption of the main candidate genes resulted in a reduction of enteric neurons in zebrafish. b) In parallel, we evaluated the contribution of different genetic risk factors, by comparing the contribution of known non-coding predisposing haplotypes across groups. o/e = overexpressed, $\mathrm{VI}=$ intolerant to variation .

Figure 2. ENS overexpressed genes intolerant to variation were enriched in HSCR-complex patients and their disruption in zebrafish caused HSCR phenotypes a) Graph showing CNV size, each dot represents a CNV. b) graph showing the number of variant intolerant (VI) genes overexpressed in the mouse ENS per patient, each dot represents one patient. c) Graph showing the RSnc, each dot represents one patient. Error bars represent standard deviation, statistical analysis used: students t-test (a-c). d) CRISPR/Cas9 complex injections in zebrafish fertilized eggs induced HSCR phenotypes upon disruption of four genes (accumulated data from multiple experiments). e) Graph showing accumulated data of the percentage of fish with HSCR phenotypes upon injection of a morpholino targeting Ret translation at a concentration that induced HSCR phenotypes in approximately 50\% of the fish. Ret morpholino injections in combination with disruption of mapk8 shows epistasis. Disruption of gn/1 showed a trend towards higher penetrance of HSCR phenotypes. f) A second injection round targeting gnl1, using a lower dose of ret morpholino, confirmed gnl1 epistasis with Ret.

Figure 3. Complex HSCR genetics: genetic predispositions of HSCR patient groups a) Visual representation of the distribution of genetic predispositions over HSCR patient groups. In total 197 patients born between 1973 and 2018 were evaluated by a clinical geneticist in the department of Clinical Genetics, Erasmus Medical Center, Rotterdam. Of these, 114 did not have associated anomalies nor a known syndrome. 29 patients had a known HSCR related genetic syndrome, including Down syndrome (n=18). 153 out of 197 patients were genetically evaluated for RET gene involvement and 21 had a pathogenic RET variant. b) Pie charts showing the incidence of rare CNVs containing genes overexpressed in the developing mouse ENS and coding variants in HSCR patients. c) Graphical 
medRxiv preprint doi: https://doi.org/10.1101/2020.11.02.20221481; this version posted November 4, 2020. The copyright holder for this preprint (which was not certified by peer review) is the author/funder, who has granted medRxiv a license to display the preprint in It is made available under a CC-BY-NC-ND 4.0 International license.

531 representation of a hypothetical model explaining the relative contributions of the risk scores in our 3 patient groups. Error bars represent standard deviation.

533 Table 1. Genes in rare CN losses that are overexpressed in mouse ENS and intolerant to

534 genetic variation Genes marked with an \# also have a loss of function variant in an independent

535 HSCR cohort (see table 2). Depicted are the RSnc (see S11) and the CNV and variant intolerance

536 scores derived from http://gnomad.broadinstitute.org/ and http://exac.broadinstitute.org/about.

537

538 Table 2: WES: Nonsense and splice site variants in rare CNV genes

539 Rare putative deleterious nonsense variants and variants predicted to affect splicing in a whole exome

540 sequencing cohort of HSCR ( $n=76,149$ controls) [36] and whole genome sequencing cohort of 443

541 short segment HSCR patients and 493 unaffected controls[37]. Variants in genes intolerant to

542 variation that were also impacted by the de novo 17q23.1 - q23.2 loss (INTS2, MED13), the de novo

$5436 p 22.1$ - p21.33 loss (PRRC2A, TUBB), the 9p21 loss (LINGO2), the maternal inherited 10q11.22 -

544 q11.23 loss (SGMS1), de novo 7q36.1 gain (KMT2C) and the 3q24 gain (SLC6A6). 
Table 1. Genes in rare CN losses that are overexpressed in mouse ENS and intolerant to genetic variation

\begin{tabular}{|c|c|c|c|c|c|c|c|}
\hline & & & \multicolumn{4}{|c|}{ ExAC/ GnomAD intolerance scores } & \multirow[b]{2}{*}{ CNV region } \\
\hline Patient & $\mathbf{R S}_{\mathrm{NC}}$ & Gene & Missense Z & pLI & Deletion single & Deletion CNV & \\
\hline P_000479 & 4,16 & SLC8A1 & 2.23 & 1.00 & -0.02 & 0.31 & chr2:40,624,267-40,646,501 \\
\hline \multirow[t]{3}{*}{ P_000512 } & 8,31 & TUBB & 5.71 & 0.98 & -2.85 & -1.72 & \multirow[t]{3}{*}{ chr6:28,005,012-31,683,185 } \\
\hline & & GNL1 & 2.52 & 1.00 & 1.03 & 0.70 & \\
\hline & & GABBR1 & 4.98 & 1.00 & 1.36 & 1.23 & \\
\hline P_000537 & 6,92 & MAPK8 & 2.92 & 1.00 & 0.84 & -2.25 & chr10: 49,033,586 -52,431,193 \\
\hline P_000561 & 6,08 & UFD1L & 2.77 & 1.00 & 1.06 & -2.53 & chr22:18,861,209-21,630,630 \\
\hline \multirow[t]{2}{*}{ P_000567 } & 7,98 & TBX2 & 1.75 & 0.99 & -0.01 & 0.53 & \multirow[t]{2}{*}{ chr17:58,076,721-60,362,868 } \\
\hline & & USP32 & 3.55 & 1.00 & -2.85 & -0.93 & \\
\hline P_002431 & 9,37 & AKT3 & 4.03 & 1.00 & -2.61 & -1.20 & chr1:243,963,527-244,016,804 \\
\hline
\end{tabular}


Table 2: WES: Nonsense and splice site variants in rare CNV genes in HSCR patients

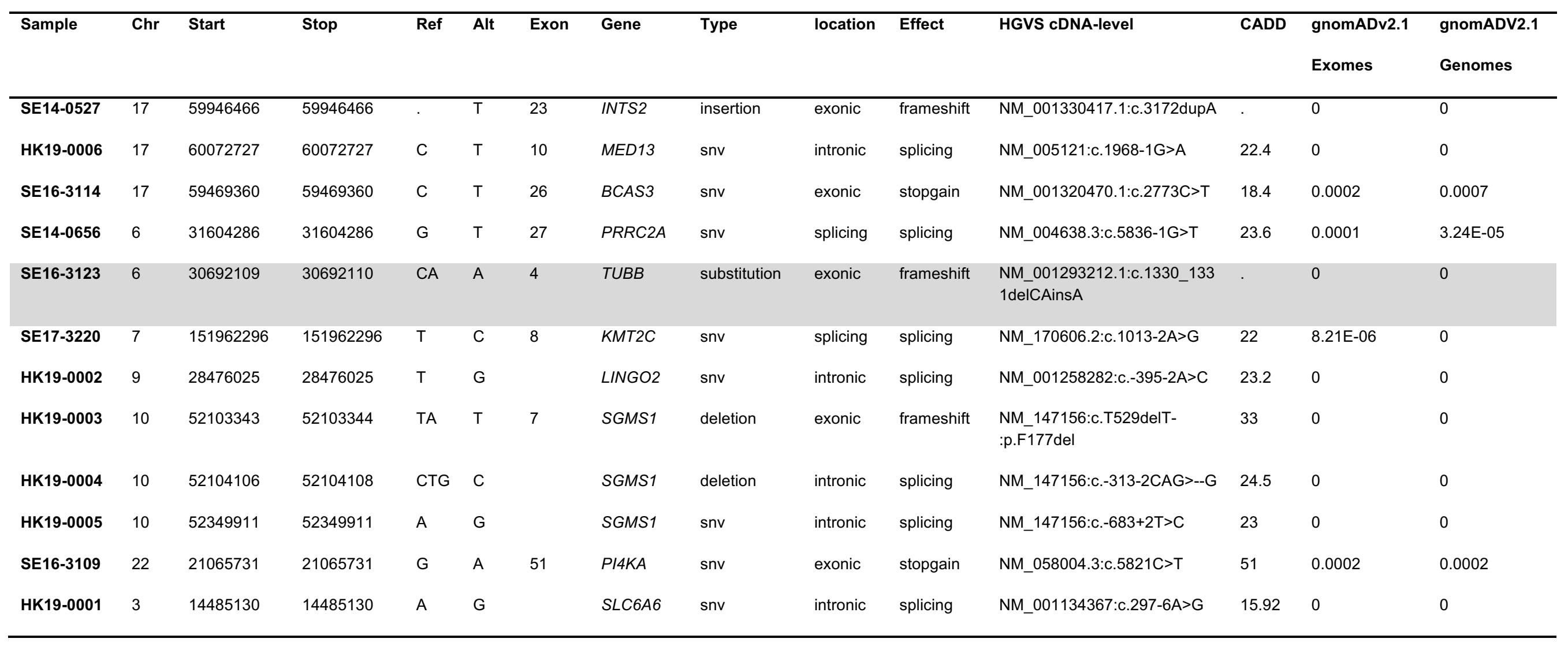


medRxiv preprint doi: https://doi.org/10.1101/2020.11.02.20221481; this version posted November 4 , 2020. The copyright holder for this preprint (which was not certified by peer review) is the author/funder, who has granted medRxiv a license to display the preprint in perpetuity.

Figure 1

HSCR patients

controls

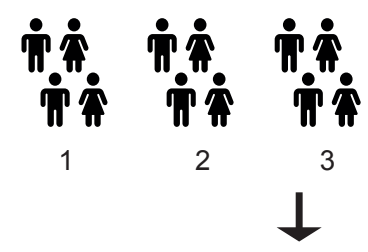

CNV

analysis

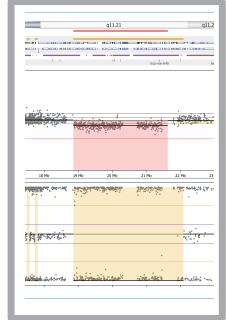

HSCR coding variants
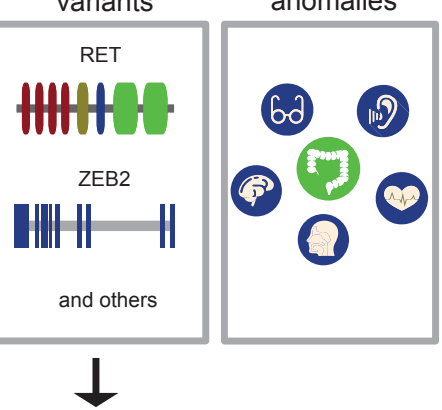

rare CNV

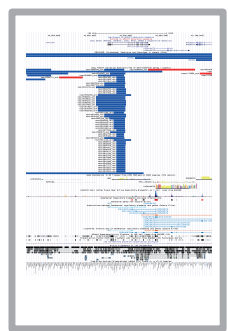

ENS
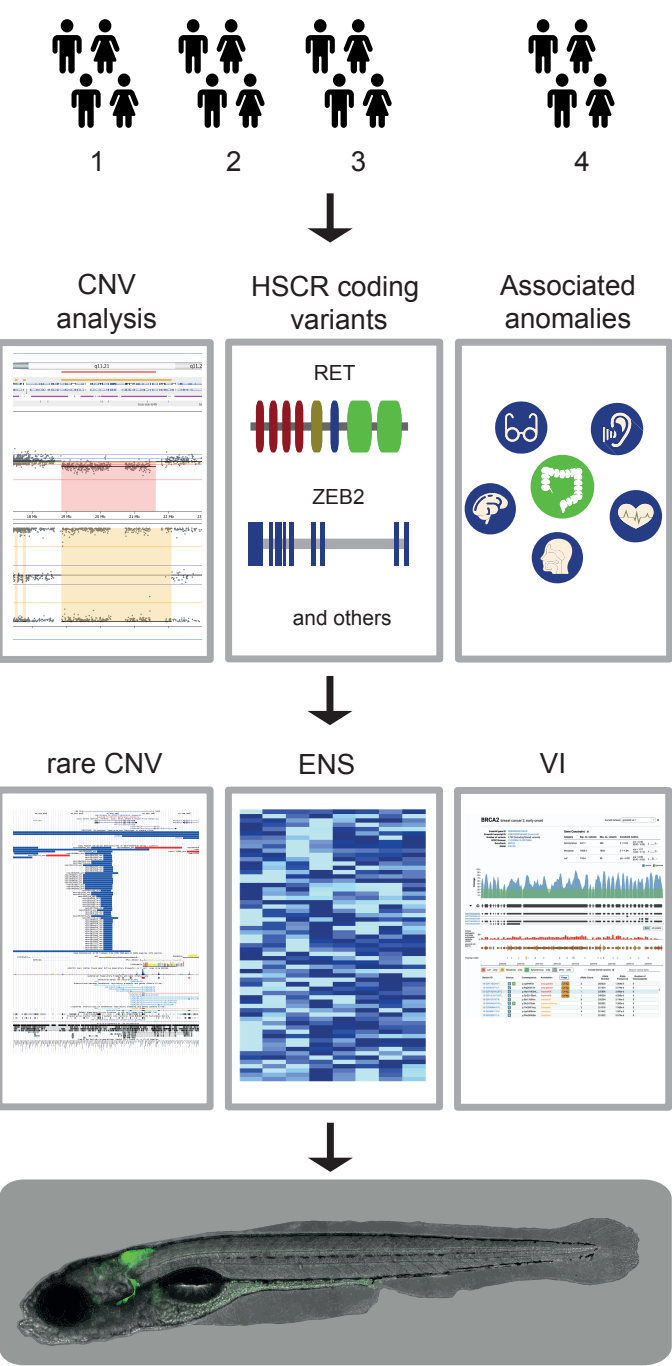

Associated anomalies
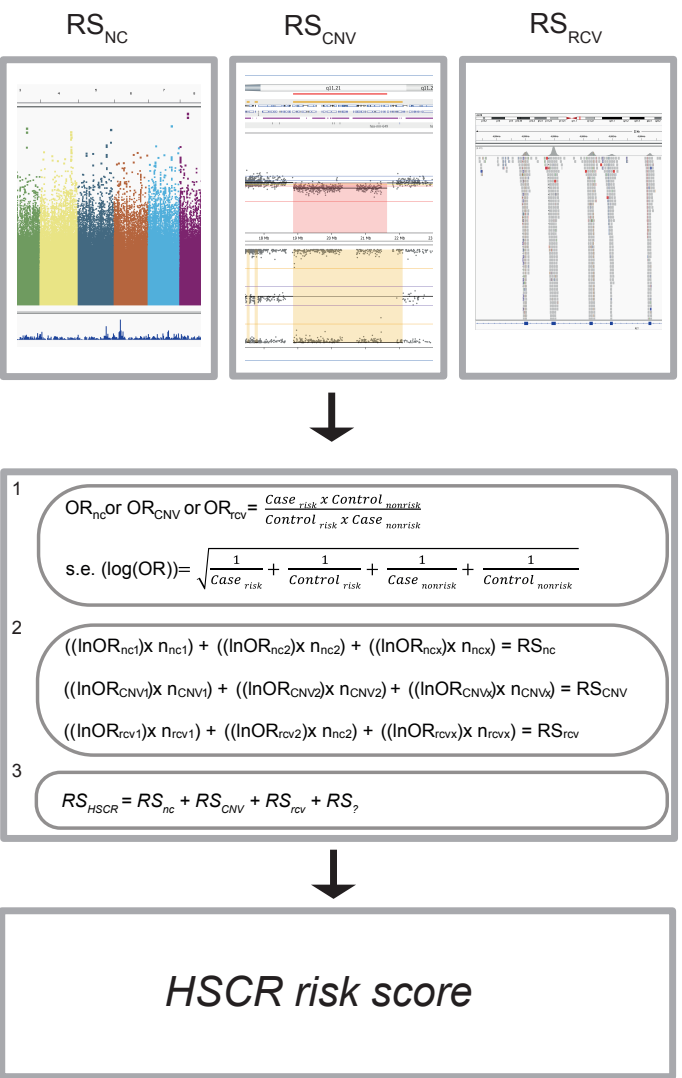
medRxiv preprint doi: https://doi.org/10.1101/2020.11.02.20221481; this version posted November 4, 2020. The copyright holder for this preprint (which was not certified by peer review) is the author/funder, who has granted medRxiv a license to display the preprint in

Figure 2

a

d

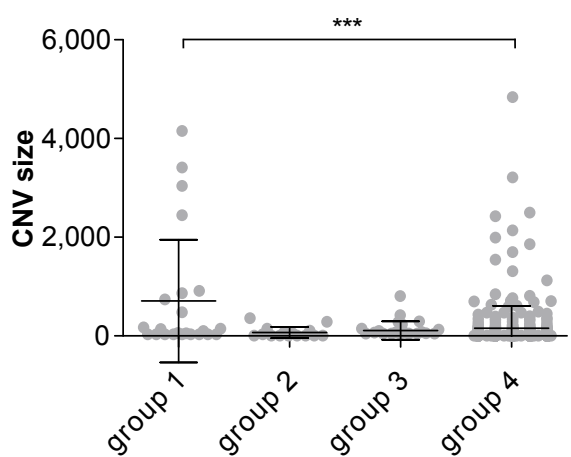

b

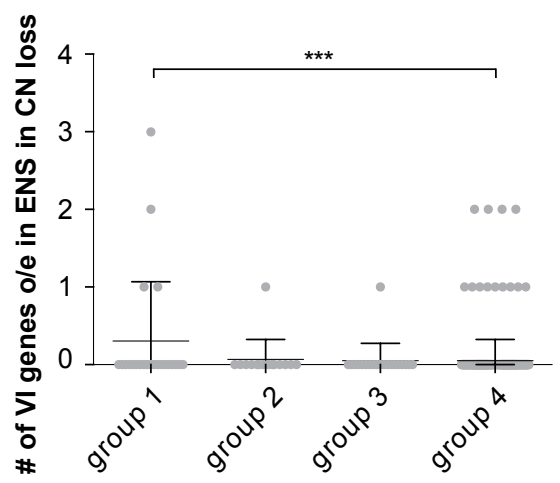

c

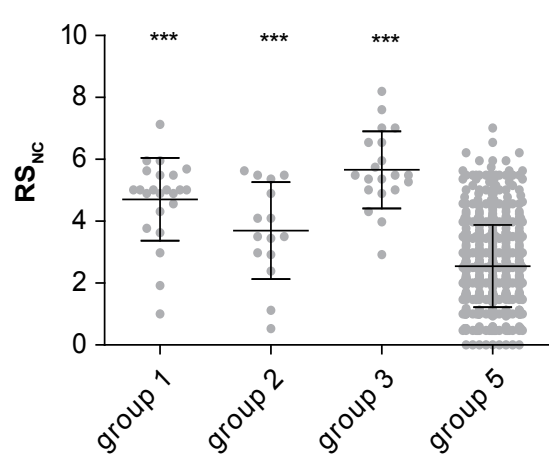

ribonucleoprotein complex (crRNA:tracrRNA:Cas9)
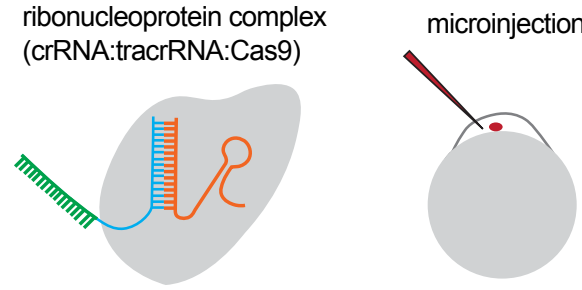


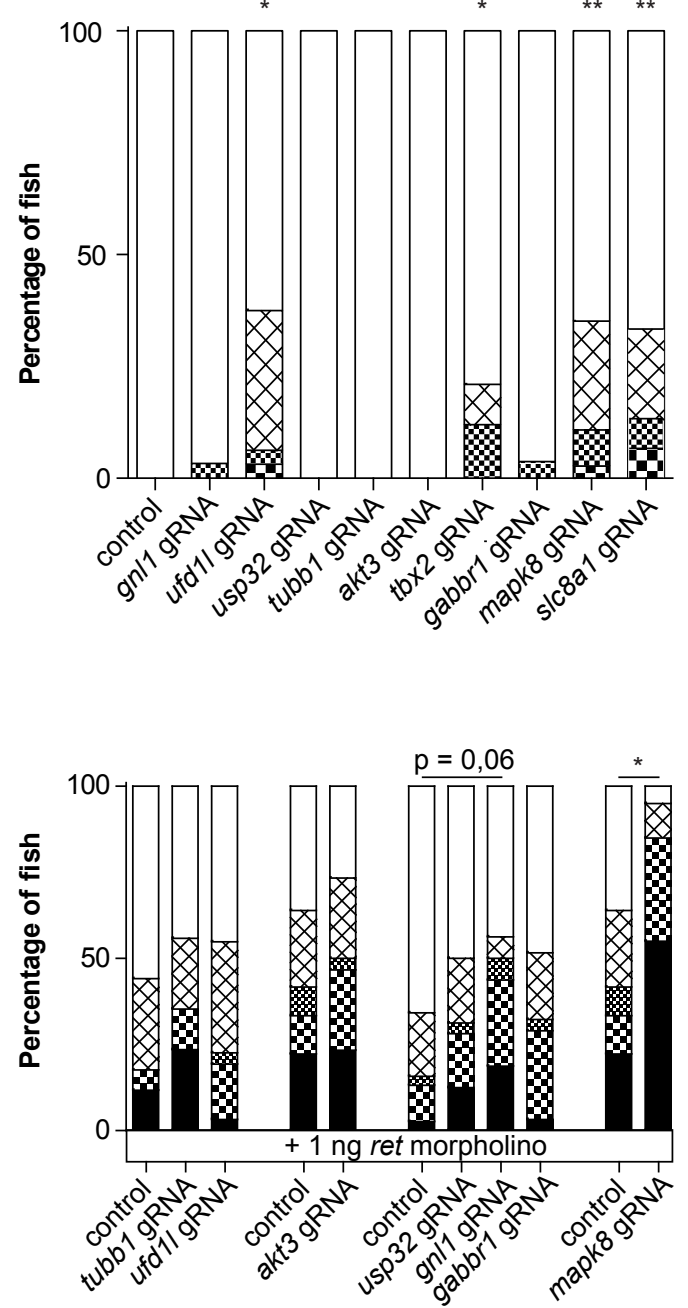

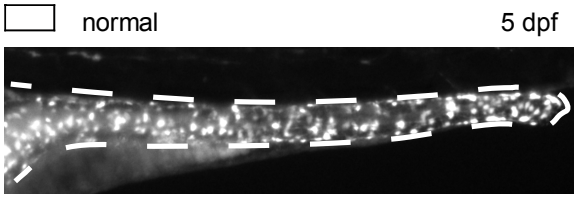

$\bigotimes$ hypogangliosis

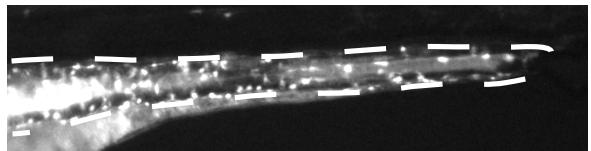

\& ultra-short segment HSCR

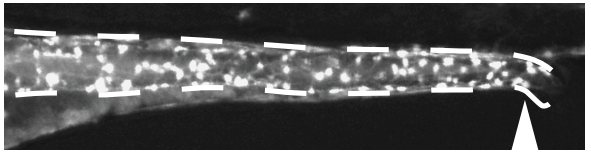

Short segment HCSR

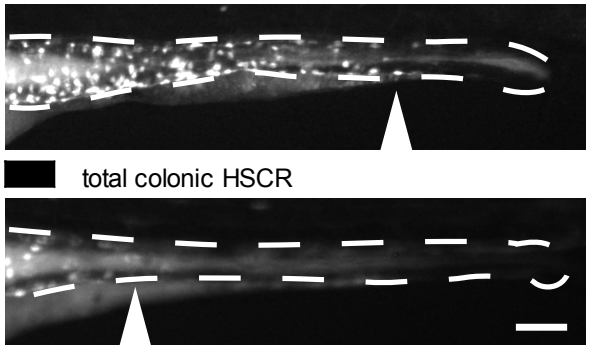

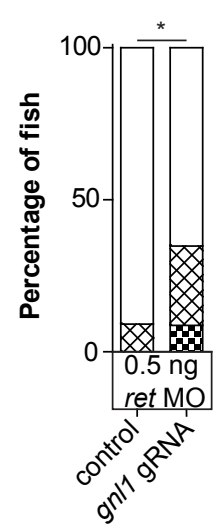

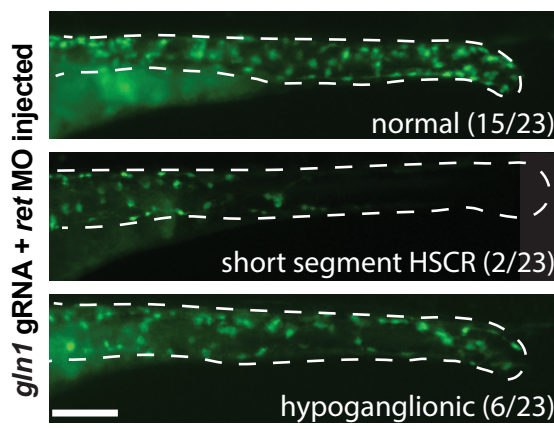


medRxiv preprint doi: https://doi.org/10.1101/2020.11.02.20221481; this version posted November 4, 2020. The copyright holder for this preprint (which was not certified by peer review) is the author/funder, who has granted medRxiv a license to display the preprint in

\section{Figure 3} group $1 \quad$ group $2 \quad$ group 3

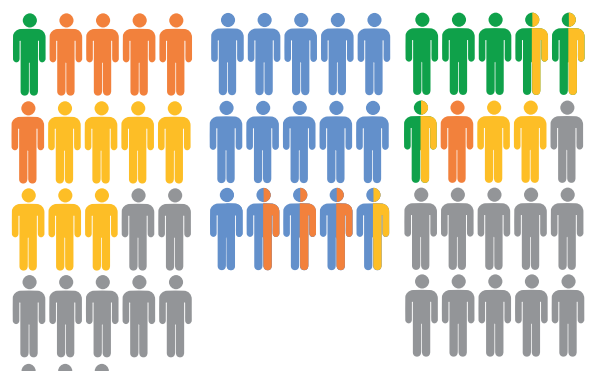

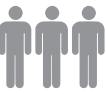

in No clear genetic indication

in HSCR coding variant

if $\mathrm{RS}_{\mathrm{NC}}>6$

if Rare CNV containing ENS o/e gene(s)

i Rare CNV containing VI ENS o/e gene(s) perpetuity.

It is made available under a CC-BY-NC-ND 4.0 International license.

b

$$
\begin{array}{cc}
\text { Patients in group 1-3 } & \text { Total patients evaluated } \\
(\mathrm{n}=58) & \text { for } \operatorname{RET}(\mathrm{n}=130)
\end{array}
$$
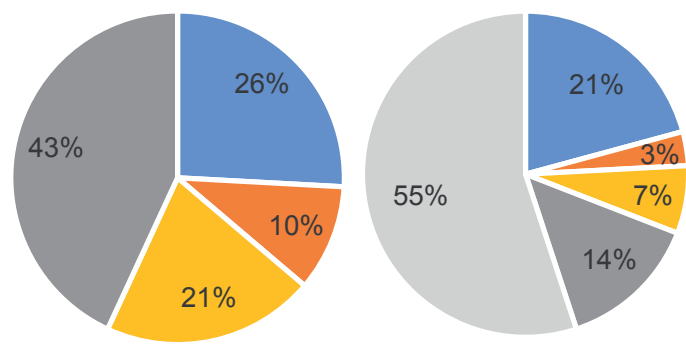

- HSCR coding variant

- Rare CNV containing ENS o/e gene(s)

- Rare CNV containing VI ENS o/e gene(s)

No coding variants in RET or rare CNVs

No coding variants in $R E T$, no $\mathrm{CN}$ prolifing done

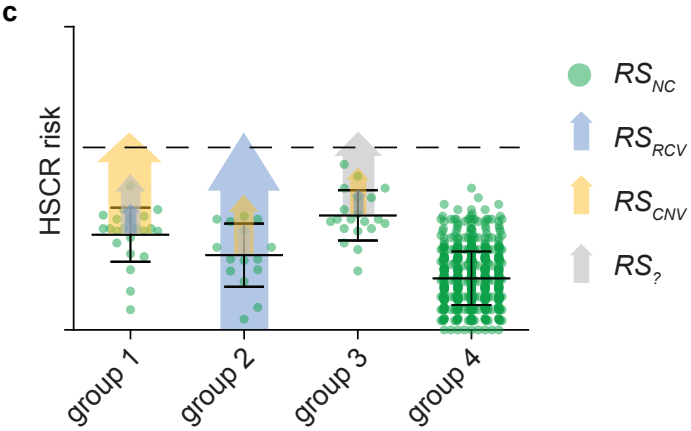

